\title{
Flow seasonality and fish assemblage in a tropical river, French Guiana, South America
}

\author{
Francisco Leonardo Tejerina-Garro ${ }^{1}$ and Bernard de Mérona ${ }^{2}$
}

The objective of this study is to verify the existence of a seasonal pattern of variation in the fish assemblages of a tropical river using taxonomic and functional descriptors. Fish were sampled using gillnets at two sites on the Comté River, a large-sized river $254.8 \mathrm{~km}$ long, flowing entirely through rainforest areas of French Guiana. Samplings were conducted every other month from August 1998 to July 2000. Four types of fish assemblage descriptors were used: the species descriptor (number of individual fish of each species in the sample); the family descriptor (number of individual fish of each family in the sample); the trophic descriptor (distribution of the fish biomass in each feeding guild) and the specific maximum observed size - MOS (number of individual fish in each of four classes of MOS: $<100 \mathrm{~mm}$; 101-200 mm; 201-300 mm; > $300 \mathrm{~mm}$ ). Results point out that changes in the fish assemblage are related to water level oscillations. The role of migration seems to be weak and is limited to trophic displacements characteristic of few species. In the low-water season, characterized by weak water level oscillation, fish species and families belonging to piscivorous or aquatic invertivorous guilds were predominant, whereas in the high-water season the environment is submitted to strong variations caused by fast and large water level oscillations, and the fish assemblage was characterized by species or families with an opportunistic omnivorous diet.

O objetivo deste estudo é verificar a existência de um padrão sazonal da variabilidade das assembleias de peixes de um rio tropical utilizando descritores taxonômicos e funcionais. Os peixes foram amostrados em duas estações localizadas ao longo dos 254,8 km do rio Comté, o qual drena regiões de floresta úmida da Guiana Francesa. As amostragens foram realizadas bimensalmente de agosto de 1998 a julho de 2000 utilizando-se redes de espera. Quatro tipos de descritores da assembleia de peixes foram utilizados: espécies (número de indivíduos de cada espécie na amostra); família (número de indivíduos de cada família na amostra); trófico (distribuição da biomassa de peixes de cada grupo trófico presente na amostra) e o tamanho máximo observado - TMO (número de indivíduos em cada uma das quatro classes de TMO: < 100 mm; 101-200 mm; 201-300 mm; > 300 $\mathrm{mm}$ ). Os resultados indicam que as mudanças na assembleia de peixes estão relacionadas à oscilação sazonal do nível da água. O papel desempenhado pelas migrações parece fraco e é limitado a deslocamentos tróficos característicos de determinadas espécies. No período da seca, caracterizado por uma fraca oscilação do nível da água, as espécies e famílias predominantes são piscívoras ou invertívoras aquáticas, enquanto que no período da chuva, o ambiente é submetido a fortes mudanças, provocadas por rápidas e amplas oscilações do nível da água, onde as espécies ou famílias características são omnívoras.

Key words: Comté River, Amazon region, Functional descriptors.

\section{Introduction}

Disturbance is an important element of environmental variation in lotic systems caused by changes in flow (Townsend \& Hildrew, 1994). It provokes change in the habitat structure (Orth, 1987), and limits the distribution and abundance of riverine species (Poff et al., 1997). Thus, in water courses where flooding is negligible, such as in a small stream, the fish assemblage structure is persistent, suggesting that biotic interactions play an important role in fish population regulation (Moyle \& Vondracek, 1985).

On the other hand, in water courses where the variability in the flow regime is high, the mean fish extinction rates are higher (Taylor \& Warren Jr., 2001). This temporal variation of stream flow is likely to allow for even greater diversity if ecologically similar species can operate in different seasons, that is, niche control by means of temporal resource differences (Townsend, 1989). Temporal variability of fish

${ }^{1}$ Centro de Biologia Aquática, Pontifícia Universidade Católica de Goiás. Av. Engler, Jardim Mariliza, CP 86, 74605-010 Goiânia, GO, Brazil.garro@ucg.br

${ }^{2}$ Institut de Recherche pour le Développement - LEHF, Université Claude Bernard Lyon1, 43 bd. 11 nov. 1918, 69622, Villeurbanne Cedex, France. bernard.de-merona@univ-lyon1.fr 
assemblages is common in streams of temperate regions where seasonal environmental changes can be large (e.g. Grossman \& Ratajczak, 1998 in the Coweeta River, North America). Seasonal variability was also described in large tropical rivers, which show both large and regular water level fluctuations (Welcomme, 1979; Mérona, 1986, 1987; Lowe-McConnell, 1987; Mérona \& Bittencourt, 1993; Lytle \& Poff, 2004). In these cases, the seasonal flooding provokes large predictable changes in the environment and there is a hypothesis that this is the main factor controlling the biota (see the flood pulse concept of Junk et al., 1989).

In this context, fish populations have developed strategies (life-history, behavioral and morphological; Lytle \& Poff, 2004) to utilize available habitats. Large-scale migrations ensure dispersal and spawning and result in large densities of some species in the main channel of rivers during some periods of the year (Bonetto, 1963; Godoy, 1967; Bayley, 1973; Ribeiro, 1983; Carvalho \& Mérona, 1986). Lateral migrations between the floodplain and the main channel of large rivers can be linked to feeding strategies as well as strategies for shelter (Cox-Fernandes \& Mérona, 1988; Cox-Fernandes, 1997; Melo et al., 2007), which seasonally modify the relative abundance of fish populations in the assemblage.

Apart from these large tropical floodplain rivers, the tropics also include rivers with steep courses where large floodplains are absent and whose hydrological regime is greatly influenced by the local rainfall. According to Huston (1979), Reice (1985) and Reice et al. (1990) this situation maintains the biological communities in a state of perpetual disequilibria, because the process of competition cannot be effective between two consecutive disturbances. Additionally, in these nonfloodplain rivers, species have a long reproductive season compared to those in large floodplain rivers, where most species exhibit a synchronism in their reproductive strategies (Ponton \& Mérona, 1998). Under these conditions seasonal patterns in non floodplain rivers could be absent or very discrete.

The objective of this study was to verify the existence of a seasonal pattern of variation in fish assemblages in a large tropical river using taxonomic and functional descriptors of fish assemblages.

\section{Material and Methods}

\section{Study Area}

The data used in this study were sampled at two sites on the Comté River, a large-sized river, 254.8 km long, flowing entirely through rainforest areas of French Guiana (Fig. 1). In each sampling site a stretch of $1000 \mathrm{~m}$ was marked using ribbons, thus fish samples were always taken in the same stretch. Sampling sites were chosen considering terrestrial and aquatic access and logistic support. The uppermost site was situated at $77.7 \mathrm{~km}$ from the river source, upstream from the village of Cacao, where intensive agriculture is the principal economic activity. The main channel (30 to $40 \mathrm{~m}$ width; water depth average over the sampling period $=3.0 \pm 1.4 \mathrm{~m}$ ) is bordered by continuous riparian vegetation, which is integrated to a dense ombrophile forest (land forest). During the rainy season, flooded areas are those where there is a mixture of shrubs and trees, but there is no typical well defined floodplain. Riffles are common, although there are no significant geomorphological discontinuities that could block fish movements, such as waterfalls. The lowermost site was located at $101.1 \mathrm{~km}$ from the source, downstream from Cacao village and about $51.3 \mathrm{~km}$ from the estuary. The main channel is large (50-70 $\mathrm{m}$ wide) and the water depth average over the sampling period was $4.2 \mathrm{~m} \pm 1.0$. Riparian vegetation is continuous and primarily composed of tall trees, although trees are smaller in coastal plain forests. There were no floodplain areas or riffles in the lower site. Tidal influence is signaled by a daily inversion of water current but without saline penetration.

These two sites were selected after considering the general geomorphological pattern of rivers in French Guiana as described by Tito de Morais \& Lauzanne (1994) for the Sinnamary River, in other words, two contrasting zones: a long upper course with a succession of pools separated by rapids and a lower course with a low gradient of altitude, where the river crosses the coastal plain. The high-water period (rainy season) extends from November to July and the low-water (dry season) from August to October (Mérigoux et al., 1998; Fig. 2).

\section{Fish sampling}

In each river stretch fish were sampled with gillnets following the protocol suggested by Tejerina-Garro \& Mérona (2001) for large tropical rivers. Accordingly, four sets of gillnets were used, each one composed of five nets of mesh sizes 15, 20, 25, 30 and $35 \mathrm{~mm}$ between adjacent knots. Each net was 25 $\mathrm{m}$ long and $2 \mathrm{~m}$ high. They were set parallel to the shore, in places with low current along an $800 \mathrm{~m}$-stretch. They were deployed at 5 p.m. and retrieved at 7 a.m. Sampling at both sites was undertaken every other month from August 1998 to July 2000, except in December 1998 and June 1999 when sampling was delayed by logistic constraints.

In the field, all fish collected were identified to species

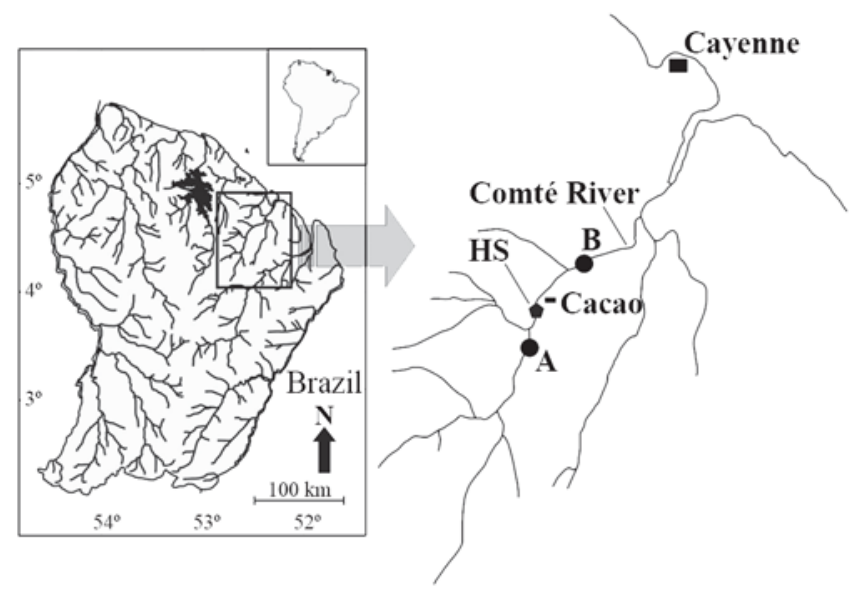

Fig. 1. Localization of the sampling sites on the Comté River, French Guiana. A = upstream site; $\mathrm{B}=$ downstream site; HS = Hydrological station. 


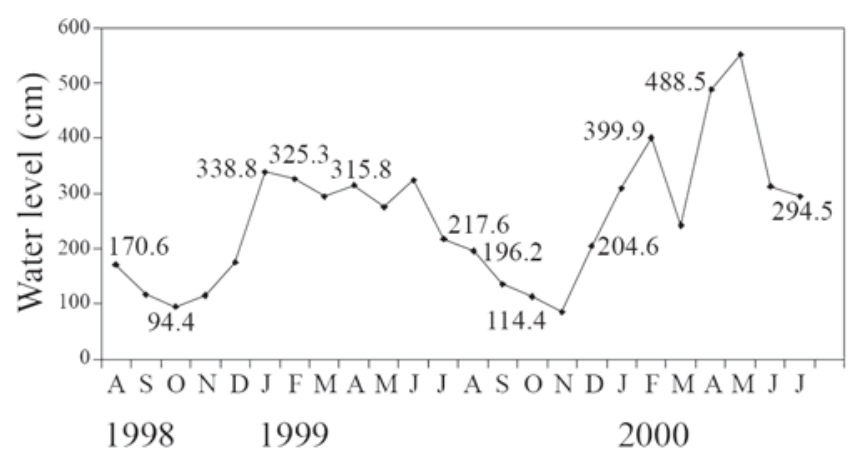

Fig. 2. Water level oscillation measured between August 1998 and July 2000 at the Hydrological station on the Comté River. The numbers indicate the mean water level during the month of sampling.

level following Planquette et al. (1996), Keith et al. (2000) and Le Bail et al. (2000). Each specimen was measured for length (standard length in $\mathrm{mm}$ ) and weight (g). Stomachs were removed and preserved in $70 \%$ alcohol for subsequent quantitative and qualitative content analyses in the laboratory.

Seven specimens of each species collected were preserved in $70 \%$ alcohol and deposited in the regional fish collection of the Institut de Recherche pour le Développement in French Guiana.

\section{Determination of trophic guilds}

To obtain a broader image of the general feeding patterns while excluding a possible interference by opportunistic feeding behavior, trophic guilds of species were determined from material collected in this study (August 1998 to July 2000) and from samples collected along the same period for other purposes in other French Guiana rivers. The stomach contents were analyzed with a stereomicroscope and the volumetric percentage of each alimentary item was estimated visually following the "point method" (Zavala-Camin, 1996). Afterwards the average percentage was calculated for each alimentary item and per species. The following items were considered: superior plants (leaves, wood, roots, fruits and seeds); aquatic invertebrates (insects and others such as shrimps and crabs); terrestrial invertebrates (insects and others such as spiders and myriapodes); fish; and detritus, including sediment and organic layers (algae).

Trophic guilds were determined by considering the predominant item, that is $>40 \%$ in the average content. When a species consumed both vegetal and animal matter, it was considered to be omnivorous.

Determination of the feeding regime of species can be affected by ontogeny (Winemiller, 1989) or by the opportunistic feeding behaviour of fishes (Matthews, 1998). In our study, the influence of ontogeny was considered negligible because only adults were considered in the analysis of stomach contents. The influence of opportunism was also limited by adopting a method based on item predominance. When the number of stomachs available for analysis was $<20$, the feeding regime was confirmed with data available in the published literature.

\section{Fish assemblage descriptors}

Four descriptors of fish assemblage were used to examine assemblage variation along the study period. These included the number of individual fish of each species in the sample and the number of individual fish of each family in the sample (both taxonomic descriptors). The trophic descriptor quantifies the distribution of fish biomass in each feeding guild and is used as a functional descriptor of the assemblage. The fish biomass is a useful tool for elucidate major trophic interactions in freshwater fish communities (Leeuw et al., 2003). The maximum observed size (MOS) is the number of individual fish in each of four MOS classes: $\leq 100 \mathrm{~mm}$; 101$200 \mathrm{~mm}$; 201-300 mm; > $300 \mathrm{~mm}$. Maximum size of species is generally associated with other life-history parameters, such as age at maturity and annual reproductive investment, but it could also be related to the intensity of fish movement over substantial space or migration.

\section{Data analysis}

To prevent the introduction of variability linked to the chance capture of rare species, species with $\leq 10$ specimens were eliminated from the analysis. To describe assemblages in upstream and downstream sites a Correspondence Analysis (CA), a one-table ordination method, was conducted separately for each sampling site and descriptor using the ADE-4 software (Thioulouse et al., 1997). CA is often used for faunistic tables where the counts are the abundance (density, presence or absence) of a species in a sample. The absolute abundances are first transformed into relative abundances and then the modeling of data consists of a double centering (Dolédec \& Chessel, 1991).

The relationship between the variability of fish assemblages and the seasonal hydrologic variability was tested by regressing the sample coordinates on the first two axes of the CA against the mean water level in the month of sampling, using the SYSTAT ${ }^{\circledR} 9$ software.

\section{Results}

After elimination of rare species, 5614 individuals were registered in the upstream $(\mathrm{n}=3240)$ and downstream $(\mathrm{n}=$ 2374) sites. These fish, which represent $80.2 \%$ of the total capture, included 37 species, 14 families and 5 orders (Table 1).

\section{Trophic guilds}

We analyzed 2707 stomachs pertaining to 36 of the 37 species retained for analyses. Twelve species had their diet confirmed by literature data because of insufficient stomach samples $(<20)$. In the case of Ageneiosus ucayalensis, the observed diet (fish and aquatic invertebrates) did not coincide with that of the literature data (fish and decapods; Mérona et al., 2001), so it was considered to be a piscivore. We were unable to find any reference on the feeding habits of Ancistrus 
hoplogenys, but Goulding et al. (1988) reported a diet based on detritus for two species of Ancistrus in the rio Negro. According to the predominance of food item in the stomachs, we grouped the 37 species into six trophic guilds: piscivore, herbivore, detritivore, aquatic invertivore, terrestrial invertivore and omnivore (Table 2).

Table 1. Fish species with their respective identification number, code and number of individuals by site collected between August 1998 and July 2000 in the Comté River, French Guiana.

\begin{tabular}{|c|c|c|c|c|}
\hline \multirow{2}{*}{ Species } & \multirow{2}{*}{$\begin{array}{c}\text { Identification } \\
\text { number }\end{array}$} & \multirow{2}{*}{ Code } & \multicolumn{2}{|c|}{ Site } \\
\hline & & & Upstream & Downstream \\
\hline \multicolumn{5}{|l|}{$\overline{\text { CLUPEIFORMES }}$} \\
\hline Engraulidae & & & 40 & 166 \\
\hline Anchovia surinamensis & 8 & ASUR & 13 & 101 \\
\hline Lycengraulis batesii & 23 & LBAT & 23 & 54 \\
\hline Pterengraulis atherinoides & 28 & PATH & 4 & 11 \\
\hline \multicolumn{5}{|l|}{ CHARACIFORMES } \\
\hline Anostomidae & & & 46 & 33 \\
\hline Leporinus friderici & 25 & LFRI & 46 & 33 \\
\hline Characidae & & & 1913 & 1016 \\
\hline Acestrorhynchus falcatus & 2 & AFAL & 125 & 85 \\
\hline Acestrorhynchus microlepis & 5 & AGUI & 329 & 173 \\
\hline Bryconops affinis & 9 & BAFF & 107 & 95 \\
\hline Bryconops caudomaculatus & 10 & BCAU & 647 & 528 \\
\hline Bryconops melanurus & 11 & BMEL & 55 & 4 \\
\hline Charax pauciradiatus & 13 & CPAU & 243 & 23 \\
\hline Jupiaba keithi & 7 & JKEI & 14 & 0 \\
\hline Moenkhausia grandisquamis & 26 & MGRA & 262 & 59 \\
\hline Piabucus dentatus & 30 & PDEN & 32 & 4 \\
\hline Poptella brevispina & 34 & PBRE & 99 & 45 \\
\hline Curimatidae & & & 251 & 205 \\
\hline Curimata cyprinoides & 12 & CCYP & 108 & 175 \\
\hline Cyphocharax sp. & 14 & CYP1 & 41 & 4 \\
\hline Cyphocharax spilurus & 15 & CYSP & 102 & 26 \\
\hline Erythrinidae & & & 40 & 11 \\
\hline Hoplias aimara & 18 & HAIM & 16 & 8 \\
\hline Hoplias malabaricus & 20 & HMAL & 24 & 3 \\
\hline Hemiodontidae & & & 166 & 244 \\
\hline Hemiodus quadrimaculatus & 22 & HQUA & 39 & 26 \\
\hline Hemiodus unimaculatus & 19 & HEUN & 127 & 218 \\
\hline Serrasalminae & & & 120 & 35 \\
\hline Myleus ternetzi & 27 & MTER & 101 & 18 \\
\hline Serrasalmus humeralis & 36 & SHUM & 19 & 17 \\
\hline \multicolumn{5}{|l|}{ GYMNOTIFORMES } \\
\hline Sternopygidae & & & 15 & 15 \\
\hline Eigenmannia virescens & 17 & EVIR & 15 & 15 \\
\hline \multicolumn{5}{|l|}{ SILURIFORMES } \\
\hline Auchenipteridae & & & 438 & 586 \\
\hline Ageneiosus inermis & 1 & ADEN & 28 & 18 \\
\hline Ageneiosus ucayalensis & 3 & AGBR & 45 & 27 \\
\hline Auchenipterus nuchalis & 6 & ANUC & 242 & 456 \\
\hline Pseudauchenipterus nodosus & 33 & PNOD & 27 & 15 \\
\hline Trachelyopterus galeatus & 32 & PGAL & 96 & 70 \\
\hline Doradidae & & & 43 & 0 \\
\hline Doras carinatus & 16 & DCAR & 43 & 0 \\
\hline Loricariidae & & & 39 & 17 \\
\hline Ancistrus hoplogenys & 4 & AHOP & 2 & 12 \\
\hline Hypostomus gymnorhynchus & 21 & HGYM & 24 & 3 \\
\hline Loricaria cataphracta & 24 & LCAT & 13 & 2 \\
\hline Pimelodidae & & & 8 & 4 \\
\hline Pimelodus blochii & 29 & PBLO & 8 & 4 \\
\hline \multicolumn{5}{|l|}{ PERCIFORMES } \\
\hline Cichlidae & & & 75 & 12 \\
\hline Satanoperca jurupari & 37 & SJUR & 75 & 12 \\
\hline Sciaenidae & & & 46 & 30 \\
\hline Pachypops fourcroi & 31 & PFOU & 30 & 14 \\
\hline Plagioscion squamosissimus & 35 & PSQU & 16 & 16 \\
\hline
\end{tabular}

\section{Seasonal variability - Fish assemblage descriptors}

Despite separate CA analysis, the fish assemblage descriptors indicated similar results in both upstream and downstream sites. The first two axes explained up to $50 \%$ of the variability in most of the cases except for the taxonomic descriptor (species) in the downstream site (fraction explained $=42 \%$; Table 3 ).

The correlations between the coordinates of samples on the first axis of the CA and the corresponding water levels were statistically significant except for the MOS descriptor in the downstream site (Table 4). However, correlations were weaker for the downstream site. The second axis was not correlated with water level, either in the upstream or downstream sites. This lack of correlation seems to reflect the weak contribution of axis 2 to the seasonal pattern of samples (Tables 3 and 4).

Associations of descriptors with the seasonal pattern of samples showed differences as well as similarities in both upstream and downstream sectors of the river. Two species contributed significantly to the dispersion of samples in the upstream site: Bryconops caudomaculatus for high-water and Charax pauciradiatus for low-water (Fig. 3). In the downstream site the species that contributed most to the first axis were Curimata cyprinoides and Cyphocharax spilurus, both associated with low-water. Bryconops affinis and Auchenipterus nuchalis were associated with the high-water samples (Fig. 4). In both regions the Curimatidae was characteristic of low-water samples but its contribution was much higher in the downstream site. In this downstream site, the family Engraulidae was associated with low-water samples but the opposite occurred in the upstream section. Upstream, cichlids and serrasalmids were linked to the low-water samples. Doradidae was associated with low-water samples in the upstream region and with high-water in the downstream site. The family Auchenipteridae was associated with high water in both sections (Figs. 3 and 4).

In terms of trophic guilds, terrestrial and aquatic invertivores were mainly responsible for the discrimination of samples on the first axis of the CA for both sites; the former being associated with high-water and the latter with the low-water samples. Detritivores and piscivores were also characteristic of lowwaters in both sections of the river (Figs. 3-4).

Only in the upstream site did the MOS descriptor discriminate the samples on a seasonal basis. Upstream, the largest species (MOS > $301 \mathrm{~mm}$ ) were associated with the lowwater season and the small (MOS $<100 \mathrm{~mm}$ ) and medium sized ones $(201<$ MOS $<300 \mathrm{~mm}$ ) with the high-water season (Fig. 3).

\section{Discussion}

\section{The general pattern of seasonal variability}

Floods are predictable disturbances in continental lotic ecosystems of temperate (Poff et al., 1997) and tropical regions (Welcomme, 1979; Lowe-McConnell, 1987). These perturbations cause changes of certain hydraulic parameters such as flow velocity and water level (Poff et al., 1997), which 
Table 2. Number of stomachs analyzed (n), percentage of alimentary items found and trophic guild by fish species. * = trophic guild confirmed by literature; $\mathrm{D}=$ Detritivores; $\mathrm{AI}=$ Aquatic invertivores; $\mathrm{H}=$ Herbivores; $\mathrm{O}=$ Omnivores; $\mathrm{P}=$ Piscivores; TI = Terrestrial invertivores.

\begin{tabular}{|c|c|c|c|c|c|c|c|}
\hline \multirow[b]{2}{*}{ Species } & \multirow[b]{2}{*}{$\mathrm{n}$} & \multicolumn{5}{|c|}{ Item } & \multirow[b]{2}{*}{$\begin{array}{l}\text { Thophic } \\
\text { guild }\end{array}$} \\
\hline & & $\begin{array}{c}\text { Superior } \\
\text { plants }\end{array}$ & $\begin{array}{c}\text { Aquatic } \\
\text { invertebrates }\end{array}$ & $\begin{array}{c}\text { Terrestrial } \\
\text { invertebrates }\end{array}$ & Fish & Detritus & \\
\hline \multicolumn{8}{|l|}{ CLUPEIFORMES } \\
\hline \multicolumn{8}{|l|}{ Engraulidae } \\
\hline Anchovia surinamensis & 20 & - & 81.00 & 5.00 & - & 14.00 & AI \\
\hline Lycengraulis batesii & 15 & - & 20.00 & 5.33 & 58.67 & 16.00 & $\mathrm{P}^{*}$ \\
\hline Pterengraulis atherinoides & 9 & - & 33.33 & - & 66.67 & - & $\mathrm{P}^{*}$ \\
\hline \multicolumn{8}{|l|}{ CHARACIFORMES } \\
\hline \multicolumn{8}{|l|}{ Anostomidae } \\
\hline Leporinus friderici & 136 & 72.79 & 0.81 & 13.31 & 3.97 & 9.12 & $\mathrm{H}$ \\
\hline \multicolumn{8}{|l|}{ Characidae } \\
\hline Acestrorhynchus falcatus & 33 & - & - & - & 100.00 & - & $\mathrm{P}$ \\
\hline Acestrorhynchus microlepis & 30 & - & 6.67 & 15.67 & 77.67 & - & $\mathrm{P}$ \\
\hline Bryconops affinis & 197 & 6.80 & 0.76 & 90.41 & 1.12 & 0.91 & TI \\
\hline Bryconops caudomaculatus & 429 & 8.30 & 0.12 & 88.53 & - & 3.05 & TI \\
\hline Bryconops melanurus & 83 & 13.01 & - & 84.82 & - & 2.17 & TI \\
\hline Charax pauciradiatus & 32 & 4.69 & 31.25 & 31.56 & 21.88 & 10.63 & $\mathrm{O}$ \\
\hline Jupiaba keithi & 4 & 35.00 & - & 65.00 & - & - & $\mathrm{TI}^{*}$ \\
\hline Moenkhausia grandisquamis & 181 & 49.78 & 0.88 & 44.59 & 0.66 & 4.09 & $\mathrm{O}$ \\
\hline Piabucus dentatus & 14 & 25.71 & - & 0.71 & 7.14 & 66.43 & $\mathrm{D}^{*}$ \\
\hline Poptella brevispina & 156 & 19.29 & 3.33 & 73.91 & 1.28 & 2.18 & $\mathrm{TI}$ \\
\hline \multicolumn{8}{|l|}{ Curimatidae } \\
\hline Curimata cyprinoides & 113 & 1.77 & 1.42 & 0.88 & - & 95.93 & $\mathrm{D}$ \\
\hline Cyphocharax sp. & 30 & 3.33 & 2.00 & - & - & 94.67 & D \\
\hline Cyphocharax spilurus & 53 & 5.28 & - & - & - & 94.72 & $\mathrm{D}$ \\
\hline \multicolumn{8}{|l|}{ Erythrinidae } \\
\hline Hoplias aimara & 11 & - & 27.27 & - & 72.73 & - & $\mathrm{P}^{*}$ \\
\hline Hoplias malabaricus & 12 & 3.33 & 16.67 & 5.00 & 75.00 & - & $\mathrm{P}^{*}$ \\
\hline \multicolumn{8}{|l|}{ Hemiodontidae } \\
\hline Hemiodus quadrimaculatus & 40 & 13.50 & 3.00 & 3.00 & 2.50 & 78.00 & $\mathrm{D}$ \\
\hline Hemiodus unimaculatus & 109 & 13.49 & - & 5.14 & 1.74 & 79.63 & $\mathrm{D}$ \\
\hline \multicolumn{8}{|l|}{ Serrasalminae } \\
\hline Myleus ternetzi & 137 & 97.15 & 1.46 & 0.22 & - & 1.17 & $\mathrm{H}$ \\
\hline Serrasalmus humeralis & 36 & 31.67 & 3.33 & 1.67 & 52.78 & 10.56 & $\mathrm{P}$ \\
\hline \multicolumn{8}{|l|}{ GYMNOTIFORMES } \\
\hline \multicolumn{8}{|l|}{ Sternopygidae } \\
\hline Eigenmannia virescens & 34 & 5.88 & 42.94 & 37.94 & - & 13.24 & AI \\
\hline \multicolumn{8}{|l|}{ SILURIFORMES } \\
\hline Auchenipteridae & & & & & & & \\
\hline Ageneiosus inermis & 29 & 6.90 & 10.34 & 3.45 & 64.83 & 14.48 & $\mathrm{P}$ \\
\hline Ageneiosus ucayalensis & 2 & - & 50.00 & - & 50.00 & - & $\mathrm{P}^{*}$ \\
\hline Auchenipterus nuchalis & 418 & 1.39 & 3.71 & 89.95 & 0.53 & 4.43 & TI \\
\hline Pseudauchenipterus nodosus & 5 & 20.00 & - & 60.00 & - & 20.00 & $\mathrm{TI}^{*}$ \\
\hline Trachelyopterus galeatus & 202 & 41.83 & 2.43 & 50.40 & 2.43 & 2.92 & $\mathrm{O}$ \\
\hline Doradidae & & & & & & & \\
\hline Doras carinatus & 35 & 2.86 & 36.00 & 11.43 & 1.71 & 48.00 & $\mathrm{O}$ \\
\hline Loricariidae & & & & & & & \\
\hline Ancistrus hoplogenys & - & - & - & - & - & - & $\mathrm{D}^{*}$ \\
\hline Hypostomus gymnorhynchus & 13 & - & - & - & - & 100.00 & $\mathrm{D}^{*}$ \\
\hline Loricaria cataphracta & 10 & - & 43.00 & 14.00 & - & 43.00 & $\mathrm{O}^{*}$ \\
\hline Pimelodidae & & & & & & & \\
\hline Pimelodus blochii & 3 & 13.33 & 6.67 & 46.67 & 13.33 & 20.00 & $\mathrm{TI}^{*}$ \\
\hline PERCIFORMES & & & & & & & \\
\hline Cichlidae & & & & & & & \\
\hline Satanoperca jurupari & 32 & - & 15.94 & 9.06 & 5.63 & 69.38 & $\mathrm{D}$ \\
\hline Sciaenidae & & & & & & & \\
\hline Pachypops fourcroi & 23 & 6.52 & 14.78 & 58.26 & - & 20.43 & TI \\
\hline Plagioscion squamosissimus & 21 & - & 23.81 & - & 76.19 & - & $\mathrm{P}$ \\
\hline
\end{tabular}

influence the distribution and structure of aquatic communities in tropical regions (Lowe-McConnell, 1987; Boujard, 1992; Ponton \& Copp, 1997; Merigoux \& Ponton, 1999). In this study and mainly in the upstream site, this influence was clearly revealed by the taxonomic, family and trophic descriptors of the fish assemblages and less clearly by the descriptor based on maximum length (MOS). Thus, both taxonomic (species and family) and functional (trophic) descriptors give interpretable results of the fish assemblage.

At both sites during high-water season, the typical fish 
Table 3. Statistics of the Correspondence Analysis (CA) by site and fish assemblage descriptor.

\begin{tabular}{|c|c|c|c|c|c|c|c|c|c|}
\hline \multirow{3}{*}{ Site } & \multirow{3}{*}{ istics } & \multicolumn{8}{|c|}{ Descriptor } \\
\hline & & \multicolumn{2}{|c|}{$\begin{array}{l}\text { Species } \\
\text { Axis } \\
\end{array}$} & \multicolumn{2}{|c|}{$\begin{array}{c}\text { Family } \\
\text { Axis } \\
\end{array}$} & \multicolumn{2}{|c|}{$\begin{array}{c}\text { Trophic guilds } \\
\text { Axis }\end{array}$} & \multicolumn{2}{|c|}{$\begin{array}{l}\text { MOS } \\
\text { Axis }\end{array}$} \\
\hline & & 1 & 2 & 1 & 2 & 1 & 2 & 1 & 2 \\
\hline \multirow[t]{2}{*}{ Upstream } & Eigenvalues & $\overline{0.4}$ & 0.17 & 0.15 & 0.05 & 0.22 & 0.05 & 0.05 & 0.01 \\
\hline & Explained fraction of total ve & 36.0 & 15.0 & 44.0 & 17.0 & 65.0 & 16.0 & 70.0 & 21.0 \\
\hline \multirow[t]{2}{*}{ Downstream } & Eigenvalues & 0.19 & 0.15 & 0.14 & 0.09 & 0.11 & 0.05 & 0.04 & 0.03 \\
\hline & Explained fraction of total variance (\%) & 23.0 & 19.0 & 33.0 & 22.0 & 50.0 & 26.0 & 49.0 & 32.0 \\
\hline
\end{tabular}

Table 4. Results of the correlations between the coordinates of samples on the axes of the Correspondence Analysis (CA) and the corresponding water levels ( $\mathrm{n}=12$ in every case).

\begin{tabular}{lcccccc}
\hline \multirow{2}{*}{ Descriptor } & \multicolumn{2}{c}{ Axis 1 } & & \multicolumn{2}{c}{ Axis 2 } \\
\cline { 2 - 3 } \cline { 5 - 6 } & $\mathrm{r}^{2}$ & $\mathrm{p}$ & & $\mathrm{r}^{2}$ & $\mathrm{p}$ \\
\hline Taxonomic & & & & & \\
$\quad$ upstream & 0.77 & 0.001 & & 0.00 & 0.793 \\
$\quad$ downstream & 0.37 & 0.021 & & 0.05 & 0.207 \\
Families & & & & & \\
$\quad$ upstream & 0.75 & 0.001 & & 0.00 & 0.835 \\
$\quad$ downstream & 0.45 & 0.010 & & 0.07 & 0.207 \\
$\quad$ Trophic guilds & & & & & \\
$\quad$ upstream & 0.69 & 0.001 & & 0.04 & 0.251 \\
$\quad$ downstream & 0.32 & 0.032 & & 0.00 & 0.843 \\
MOS & & & & & \\
$\quad$ upstream & 0.31 & 0.035 & & 0.00 & 0.628 \\
$\quad$ downstream & 0.00 & 0.502 & & 0.00 & 0.512 \\
\hline
\end{tabular}
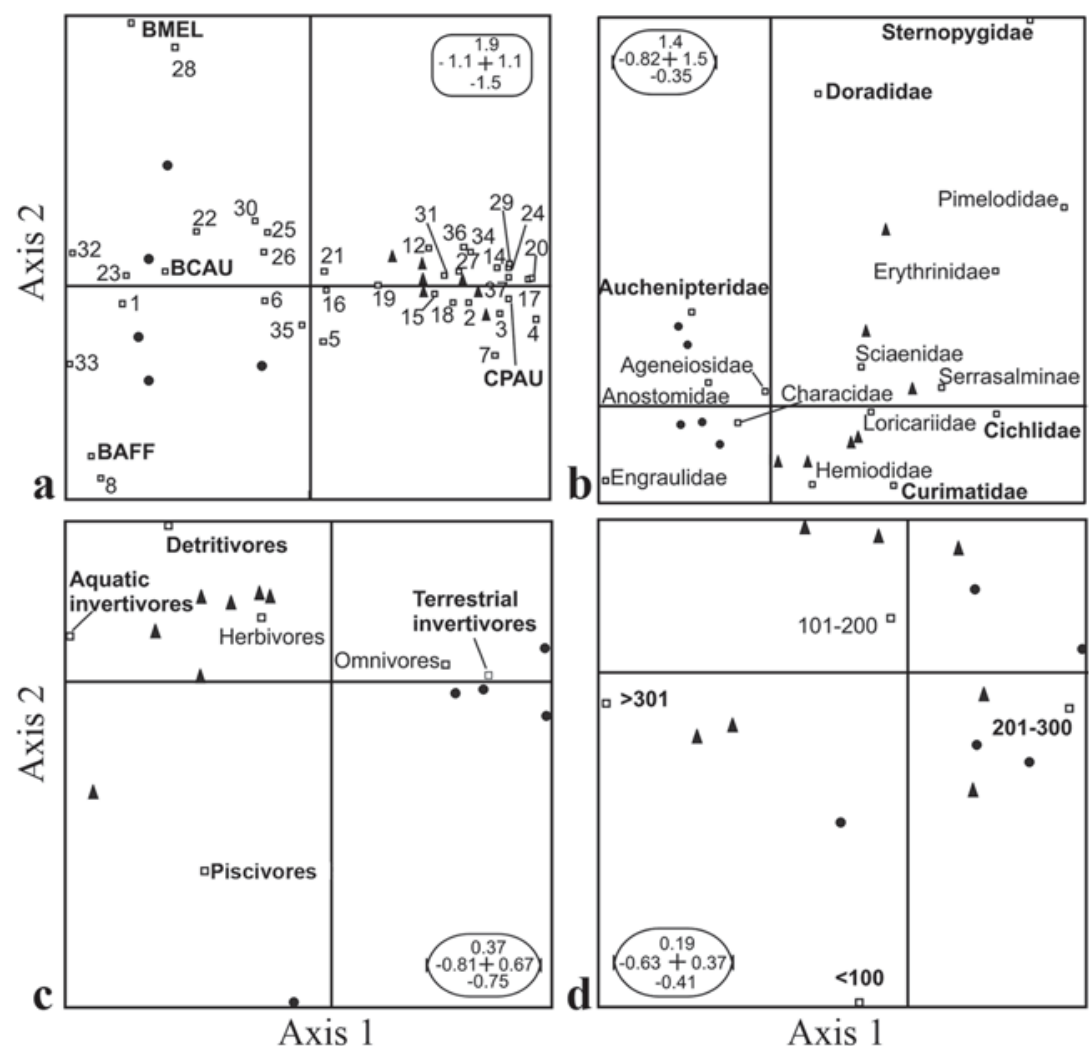

Axis 1 species were either pelagic and smaller than $100 \mathrm{~mm}$ in body size, with a diet based on terrestrial insects (e.g. Bryconops caudomaculatus, B. melanurus, B. affinis and Auchenipterus nuchalis) or $100-200 \mathrm{~mm}$ and omnivorous (e.g. Trachelyopterus galeatus). The prevalence of Bryconops species can be explained by i) the relationships between body size and life-history strategies, and ii) the type of diet and the availability of food. Indeed, Johst \& Brandl (1997) indicate that small fish species $(<100 \mathrm{~mm}$ in this study) show higher densities when compared to larger species. Moreover, small species are characterized by fast growth and rapid reactions to environmental conditions. This is the case of the three species of Bryconops, which contributed $22.6 \%$ to the total number of fish captured. These species consume mainly

Fig. 3. Fish assemblage ordination resulting from a CA analysis using species (a), family (b), trophic guild (c), and MOS (d) descriptors in the upstream site, Comté River. Bold text indicates the species, family, trophic guild or MOS which contributes most to axes. Dots = samples taken during high waters; triangles = samples taken during low waters. Numbers correspond to fish species in Table 1. Axis scales are indicated in the small box. 


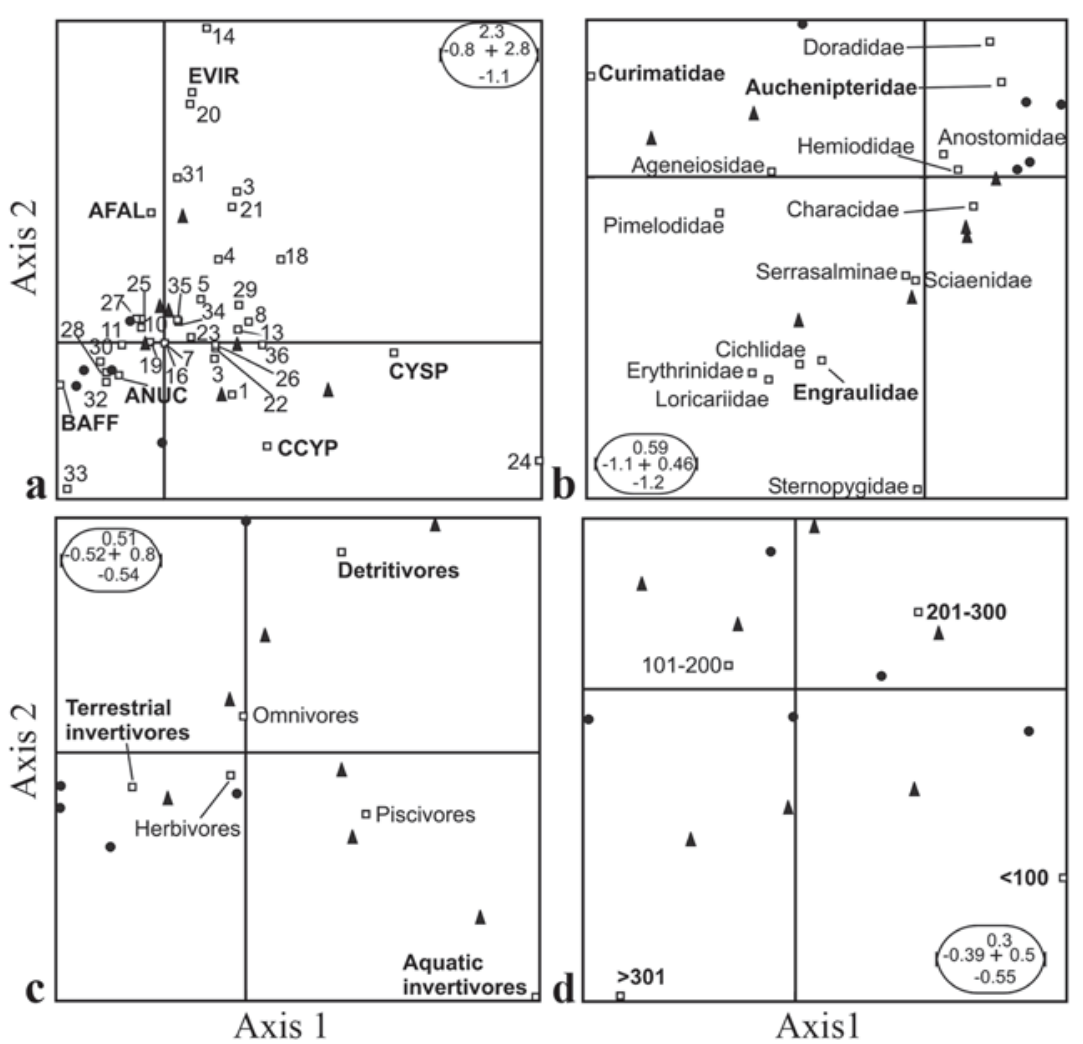

Fig. 4. Fish assemblage ordination resulting from a CA analysis using species (a), family (b), trophic guild (c), and MOS (d) descriptors in the downstream site, Comté River. Bold text indicates the species, family, trophic guild or MOS which contributes most to axes. Dots = samples taken during high waters; triangles = samples takes during low waters. Numbers correspond to fish species in Table 1. Axis scales are indicated in the small box.

terrestrial products such as insects, fruits, flowers and others items provided by the riparian vegetation (Tito de Morais et al., 1995; Mérona et al., 2005, 2008). Throughout the highwater season, floods invade the riparian forest where there are plenty of terrestrial food resources available (leaves, fruits, seeds, ants, termites, butterflies; Horeau et al., 1998). The availability and diversity of allochthonous food resources also support the presence of Auchenipterus nuchalis that feeds on terrestrial invertebrates (Mérona \& Rankin-deMérona, 2004; Mérona et al., 2005) and the omnivorous Trachelyopterus galeatus.

During the low waters the prevalent species are detritivores such as Cyphocharax cyprinoides and Cyphocharax spilurus, aquatic invertivores such as Eigenmannia virescens or predators of large (> $301 \mathrm{~mm}$ ) or small-to-medium size (101$200 \mathrm{~mm}$ ) such as Acestrorhynchus falcatus. Welcomme (1979) and Rodriguez \& Lewis Jr. (1997) mentioned that predation is a major cause of fish mortality in tropical regions during the low-water season. At this time, a low-water level favors fish concentration in the main channel of rivers (Angermeier \& Karr, 1983). This situation seems to explain the presence of piscivorous species at both sites on the Comté River. The presence of detritivores such as Curimata cyprinoides and Cyphocharax spilurus, and aquatic invertivores such as Eigenmannia virescens can be explained by the type of food resource available because of the environmental characteristics prevalent during the low-water season. In this period, the input of allochthonous food (seeds, fruits, arthropods, and leaves) in the aquatic environment is reduced, since the riparian vegetation cover over the river channel is reduced because of the absence of floods (Tejerina-Garro, 2001). The aquatic environment becomes more autotrophic (presence of aquatic plants growing on the emergent rocks along the river, aquatic insects, algae and accumulation of sediments). This environment supports species that explore the aquatic trophic web, such as certain tropical fish species specialized in obtaining their food from sediment and detritus (Lowe-McConnell, 1987; Mérona et al., 2005). These results related to species descriptor seems to be confirmed by the family descriptor notably for Auchenipteridae (Auchenipterus nuchalis, Trachelyopterus galeatus) which is associated to high water, Curimatidae (Curimata cyprinoides, Cyphocharax spilurus and C. cyprinoides) and Sternopygidae (Eigenmannia virescens), these two last associated to low-water.

The relation between fish size and seasonality is not clear. In the upstream site, large fishes were associated with lowwater, and medium-sized fishes with high water. This could be related to the higher vulnerability of large fish to gillnet at a time when the water volume is considerably reduced. 


\section{The upstream-downstream gradient}

The similarities in observed results at upstream and downstream sites suggest a weak longitudinal zonation of the fish assemblage in the portion of the Comté River that we studied. These results are in accordance with those obtained by Tito de Morais \& Lauzanne (1994) in the Sinnamary River, another large-sized river in French Guiana. However, the results observed in the Comté River are surprising considering the characteristics and variability of the downstream site (daily inversion of water current because of tides but without saline penetration, width and depth of main channel, absence of rapids) in relation to the upstream site.

However, the seasonal variation involving Pterengraulis atherinoides, Anchovia surinamensis and Lycengraulis batesii (Engraulidae) is different in upstream and downstream sites. At the upstream site, these species are typical of high waters, whereas at the downstream site they are typical of low waters. These species are small (100 to $180 \mathrm{~mm}$ ) and are generally poor swimmers, incapable of getting over natural obstacles with very steep slopes, such as those observed in French Guiana rivers. However they have been found in regions distant from the estuaries. Anchovia surinamensis and Lycengraulis grossidens have been sampled by Mérona \& Bittencourt (1993) in the lago do Rei, near Manaus, $2000 \mathrm{~km}$ from the Amazon River estuary and Lycengraulis batesii and Anchovia surinamensis sampled by Tejerina-Garro et al. (1998) in the floodplain lakes of the Araguaia River, an affluent of the Amazon River. In fact, their dispersal is favored during high-waters, which flood the obstacles and link downstream and upstream regions (Planquette et al., 1996).

The causes of spatio-temporal differences of the fish assemblage can be of three different types:

a) Fish constantly seek to optimize the compromise between feeding and growth, reproduction, and protection against predators. Lévêque (1995) synthesizes this compromise as the need "to be in the right place at the right time". From an assemblage and an evolutionary perspective, each species has adopted a different compromise from that adopted by others in order to benefit from competitive advantages. Thus, some fish species, seeking to optimize their reproduction or growth migrate seasonally, whereas others stay and display parental care; this hypothesis could probably explain the presence of Engraulidae species in the upstream section during high water. In this part of the river, these species search for food resources comprised of insects that drop into the water from the riparian vegetation and small fishes that use these habitats. Conversely, the migratory hypothesis cannot be evoked for species that have the same seasonal pattern in upstream and downstream regions.

b) Reproduction, growth and mortality of each population present in the assemblage influence the changes in the relative abundance of species. The arrival of an age class of a fish population characterized by a punctual reproduction will provoke a rapid and time-limited increase in the relative abundance of that particular species; seasonal abundance of Bryconops spp. during the wet season might be attributed to this phenomenon.

c) Finally, it is not possible to exclude the bias related to fish sampling. The use of standardized gillnet sets allows for the reproducibility of results (Tejerina-Garro \& Mérona, 2001), but this capture method is based on fish activity, which can differ according to species and environmental conditions.

In this study, the fish assemblage displays a seasonal pattern detected by taxonomic (species and family) and functional (trophic) descriptors. During the low-water season characterized by a low rain frequency and weak water level oscillations, fish species and families belonging to piscivore or aquatic invertivore guilds are predominant. Throughout the rainy season, corresponding to high-water levels in the river, the environment is submitted to strong variations caused by fast and large water level oscillations, and the fish assemblage is characterized by fish and family species with an opportunistic omnivore regime.

\section{Acknowledgements}

The Direction Nationale de l'Environnement - Cayenne, Grant 2366 CPER9498, Project Water Quality, funded this research. Special thanks to M. Tarcy, R. Ruffine, J. C. Bron, R. Vigouroux and to many post-graduate students especially M. Barral for their help with the fieldwork. We thank Patrick John O'Sullivan (PUC Goiás) and Anne Mary Staunton for their revision and suggestions for English style and grammar and two anonymous reviewers for their helpful suggestions. F. L. Tejerina-Garro was supported by grant number 32801A from the Institut de recherche pour le développement - IRD.

\section{Literature Cited}

Angermeier, P. L. \& J. R. Karr. 1983. Fish communities along environmental gradients in a system of tropical streams. Environmental Biology of Fishes, 9(2): 117-135.

Bayley, P. B. 1973. Studies on the migratory characin, Prochilodus platensis (Holmberg, 1889) (Pisces: Characoidei) in the river Pilcomayo, South America. Journal of Fish Biology, 5: 25-40.

Bonetto, A. A. 1963. Investigaciones sobre migraciones de peces en los ríos de la cuenca del Plata. Ciencia y Investigación, 19(1-2): 12-26.

Boujard, T. 1992. Space-time organization of riverine fish communities in French Guiana. Environmental Biology of Fishes, 34: 235-246.

Carvalho, J. L. de \& B. de Mérona. 1986. Estudos sobre dois peixes migratórios do baixo Tocantins, antes do fechamento da barragem de Tucuruí. Amazoniana, 9(4): 595-607.

Cox-Fernandes, C. 1997. Lateral migration of fishes in Amazon floodplains. Ecology of Freshwater Fish, 6: 36-44.

Cox-Fernandes, C. \& B. de Mérona. 1988. Lateral migration of fishes on a floodplain system in the Central Amazon (Careiro Island, Lake of Rei) AM-BR. Memoria Sociedad La Salle de Ciencias Naturales, 48: 409-432.

Dolédec, S. \& D. Chessel. 1991. Recent developments in linear ordination methods for environmental sciences. Advances in Ecology, 1: 133-155.

Godoy, M. P. 1967. Dez anos de observações sobre a periodicidade migratória de peixes do Rio Mogi-Guassu. Revista Brasileira de Biologia, 27(1): 1-12. 
Goulding, M., M. L. Carvalho \& E. G. Ferreira. 1988. Rio Negro, rich life in poor water. Amazonian diversity and foodchain ecology as seen through fish communities. The Hague, SPB Academic Publishing, 200p.

Grossman, G. D. \& R. E. Ratajczak. 1998. Long-term patterns of microhabitat use by fish in a southern Appalachian stream from 1983 to 1992: effects of hydrologic period, season and fish length. Ecology of Freshwater Fish, 7(3): 108-31.

Horeau, V., P. Cerdan, A. Champeau \& S. Richard. 1998. Importance of aquatic invertebrates in the diet of rapids-dwelling fish in the Sinnamary River, French Guiana. Journal of Tropical Ecology, 14: 851-64.

Huston, M. 1979. A general hypothesis of species diversity. American Naturalist, 113: 81-101

Johst, K. \& R. Brandl. 1997. Body size and extinction risk in a stochastic environment. Oikos, 78(3): 612-617.

Junk, W. J., P. B. Bayley \& R. E. Sparks. 1989. The flood pulse concept in river-floodplain systems. In: Dodge, D. P. (Ed.). Proceedings of the International Large River Symposium. Canadian Special Publication of Fisheries and Aquatic Sciences, 106: 110-127.

Keith, P., P-Y. Le Bail \& P. Planquette. 2000. Atlas des poissons d'eau douce de Guyane. Tome 2, fascicule I. Batrachoidiformes, Mugiliformes, Beloniformes, Cyprinodontiformes, Synbranchiformes, Perciformes, Pleuronectiformes, Tetraodontiformes. Paris, Patrimoines naturels (M.N.H.N./ S.P.N.), 286p.

Le Bail, P-Y, P. Keith \& P. Planquette. 2000. Atlas de poissons d'eau douce de Guyane. Tome 2, fascicule II. Siluriformes. Paris, Patrimoines naturels (M.N.H.N./S.P.N.), 307p.

Leeuw, J. J. de, L. A. J. Nagelkerke, W. L. T. V. Densen, K. Holmgren, P. A. Jansen \& J. Vijverberg. 2003. Biomass size distributions as a tool for characterizing lake fish communities. Journal of Fish Biology, 63: 1454-1475.

Lévêque, C. 1995. L'habitat: être au bon endroit au bon moment? Bulletin Français de la Pêche et de la Pisciculture, 337/338/339: 9-20.

Lowe-McConnell, R. H. 1987. Ecological studies in tropical fish communities. Cambridge, University Press, 382p.

Lytle, D. A. \& N. L. Poff. 2004. Adaptation to natural flow regimes. Trends in Ecology \& Evolution, 19(2): 94-100.

Matthews, W. J. 1998. Patterns in freshwater fish ecology. New York, Chapman \& Hall, 756p.

Melo, T. L. de, F. L. Tejerina-Garro \& C. E. de Melo 2007. Diversidade biológica da comunidade de peixes no baixo rio das Mortes, Mato Grosso, Brasil. Revista Brasileira de Zoologia, 24: 657-665.

Mérigoux, S. \& D. Ponton. 1999. Spatio-temporal distribution of young fish in tributaries of natural and flow-regulated sections of a neotropical river in French Guiana. Freshwater Biology, 42(1): 177-98.

Mérigoux, S., D. Ponton \& B. de Mérona.1998. Fish richness and specieshabitat relationships in two coastal streams of French Guiana, South America. Environmental Biology of Fishes, 51: 25-39.

Mérona, B. de. 1986/1987. Aspectos ecológicos da ictiofauna no Baixo Tocantins. Acta Amazonica, 16/17: 109-124.

Mérona, B. de \& M. M. Bittencourt. 1993. Les peuplements de poissons du "lago do Rei”, un lac d'inondation d'Amazonie centrale: description générale. Amazoniana, 12(3/4): 415-441.

Mérona, B. de, B. Hugueny, F. L. Tejerina-Garro \& E. Gautheret. 2008. Diet-morphology relationship in a fish assemblage from a medium-sized river of French Guiana. The effect of species taxonomic proximity. Aquatic Living Resources, 21(2): 171-184.
Mérona, B. de \& J. Rankin-de-Mérona. 2004. Food resource partitioning in a fish community of the Central Amazon floodplain. Neotropical Ichthyology, 2(2): 75-84.

Mérona, B. de, G. M. Santos \& R. G. Almeida. 2001. Short term effects of Tucurui Dam (Amazonia, Brazil) on the trophic organization of fish communities. Environmental Biology of Fishes, 60: 375-392.

Mérona, B. de, R. Vigouroux \& F. L. Tejerina-Garro. 2005. Alteration of fish diversity downstream from Petit-Saut Dam in French Guiana. Implication of ecological strategies of fish species. Hydrobiologia, 551: 33-47.

Moyle, P. B. \& B. Vondracek. 1985. Persistence and structure of the fish assemblage in a small California stream. Ecology, 66(1): $1-13$.

Orth, D. J. 1987. Ecological considerations in the development and application of instream flow-habitat models. Regulated Rivers Research \& Management, 1: 171-181.

Planquette, P., P. Keith \& P-Y. Le Bail. 1996. Atlas des poissons d'eau douce de Guyane (tome 1). Paris, Collection du Patrimoine Naturel, vol. 22, IEGB - M.N.H.N., INRA, CSP, Ministère de l'Environnement, 429p.

Poff, N. L., J. D. Allan, M. B. Bain, J. R. Karr, K. L. Prestegaard, B. D. Richter, R. E. Sparks \& J. C. Stromberg. 1997. The natural flow regime. A paradigm for river conservation and restoration. BioScience, 47(11): 769-84.

Ponton, D. \& G. H. Copp. 1997. Early dry-season community structure and habitat use of young fish in tributaries of the River Sinnamary (French Guiana, South America) before and after hydrodam operation. Environmental Biology of Fishes, 50: 235-56.

Ponton, D. \& B. de Mérona. 1998. Fish life-history tactics in a neotropical river with a highly stochastic hydrological regime: the Sinnamary River, French Guiana, South America. Polskie Archiwum Hydrobiologii, 45(2): 201-24.

Reice, S. R. 1985. Experimental disturbance and the maintenance of species diversity in a stream community. Oecologia, 67: 90-97.

Reice, S. R., R. C. Wissmar \& R. J. Naiman. 1990. Disturbance regimes, resilience, and recovery of animal communities and habitats in lotic ecosystems. Environmental Management, 14 (5): 647-659.

Ribeiro, M. C. L. de B. 1983. As migrações dos jaraquis (Pisces, Prochilodontidae) no rio Negro, Amazonas, Brasil. Unpublished MSc Dissertation, Instituto Nacional de Pesquisas da Amazônia/Fundação Universidade do Amazonas, Manaus, 192p.

Rodriguez, M. A. \& W. M. Lewis Jr. 1997. Structure of fish assemblages along environmental gradients in floodplain lakes of the Orinoco River. Ecological Monographs, 67(1): 109-128.

Taylor, C. M. \& M. L. Warren Jr. 2001. Dynamics in species composition of stream fish assemblages: environmental variability and nested subsets. Ecology, 82: 2320-2330.

Tejerina-Garro, F. L. 2001. Etudes des relations habitat-poissons dans les eaux courantes de Guyane française pour l'évalutation de la qualité du milieu aquatique. Unpublished PhD Dissertation, Université de Montpellier II, Montpellier, 243p.

Tejerina-Garro, F. L, R. Fortin \& M. A. Rodríguez. 1998. Fish community structure in relation to environmental variation in floodplain lakes of the Araguaia River, Amazon Basin. Environmental Biology of Fishes, 51: 399-410.

Tejerina-Garro, F. L. \& B. de Mérona. 2001. Gill net sampling standardization in large rivers of French Guiana (South America). Bulletin Français de la Pêche et de la Pisciculture, 357/360: 227-240. 
Thioulouse, J., D. Chessel, S. Dolédec \& J. M. Olivier. 1997. ADE4: a multivariate analysis and graphical display software. Statistics and Computing, 7: 75-83.

Tito de Morais, L. \& L. Lauzanne. 1994. Zonation longitudinale des peuplements ichtyques avant mise en eau de la retenue de Petit-Saut (Guyane Française). Revue d'Hydrobiologia Tropical, 27(4): 467-83.

Tito de Morais, L., M. Lointier \& M. Hoff. 1995. Extent and role for fish populations of riverine ecotones along the Sinnamary River (French Guiana). Hydrobiologia, 303: 163-79.

Townsend, C. R. 1989. The patch dynamics concept of stream community ecology. Journal of the North American Benthological Society, 8: 36-50.

Townsend, C. R. \& A. G. Hildrew. 1994. Species traits in relation to a habitat templet for river systems. Freshwater Biology, 31: 265-275.

Welcomme, R. L. 1979. Fisheries ecology of floodplain rivers. London, Longman Group Limited, 317p.

Winemiller, K. O. 1989. Patterns of variation in life history among South American fishes in seasonal environments. Oecologia, 81: 225-241.

Zavala-Camin, L. A. 1996. Introdução aos estudos sobre alimentação natural em peixes. Maringá, Eduem, 129p.

Accepted January 6, 2010 